\title{
INFLUENCE OF MACRO- AND MICRO-ELEMENT CONTENT ON MYCELIAL GROWTH OF PHOMA SP.1
}

\author{
Maryna O. Ramanenka ${ }^{1, \#}$, Vilnis Škipars ${ }^{2}$, and Vasili A. Yarmalovich ${ }^{1}$ \\ ${ }^{1}$ Forest Protection and Wood Science Department, Belarusian State Technological University, 13A Sverdlova Str., Minsk, 220006, \\ BELARUS \\ ${ }^{2}$ Latvian State Forest Research Institute "Silava", 111 Rīgas Str., Salaspils, LV-2169, LATVIA \\ \# Corresponding author, s_m@belstu.by
}

Communicated by Dainis Edgars Ruṇǵis

\begin{abstract}
Phoma blight of conifer seedlings is poorly studied. The main causal agent in Belarus differs in DNA sequence from other described Phoma species, and has not been fully taxonomically described, and therefore has been temporarily designated Phoma sp. 1. The basic morphological and growth culture characteristics of Phoma sp. 1 have recently been published. This report provides additional data about the influence of macro- and micro-elements on the growth of Phoma $s p$. 1 in vitro to complement the description of growth culture and morphological features. It was found that addition of tricalcium phosphate and potassium chloride to the media at concentrations of $1 \mathrm{~g} / \mathrm{l}$ and $2 \mathrm{~g} / \mathrm{l}$ slows the mycelial growth by an average of 30\%. The micro-elements copper sulphate (at $50 \mathrm{mg} / \mathrm{l}$ and $100 \mathrm{mg} / \mathrm{l})$ and zinc sulphate (at $100 \mathrm{mg} / \mathrm{l})$ decreased growth by $50 \%$, $63 \%$, and $32 \%$, respectively. Urea completely inhibited Ph. sp.1 growth at 0.5 g/l. Summarising previously published information, Phoma $s p .1$ is a mesophilic acidophile, capable of forming chlamydospores in culture. Pycnidia form deep in the media only after prolonged low-temperature storage. The optimal $\mathrm{pH}$ for growth is 4.3-4.9. Constant medium aeration favours the formation of typical mycelium, proportional growth and stable biomass accumulation.
\end{abstract}

Keywords: pathogenic fungi, forest nurseries, mineral nutrients, in vitro growth conditions, phytopathology.

\section{INTRODUCTION}

Although in other countries cases of Phoma blight disease date back to the 1980s (Kliejunas et al., 1985; James, 1986; Hansen and Hamm, 1988; Srago et al., 1989; James, 1998), in Belarus this disease is considered to be new, yet already widespread (Baranov et al., 2012; Yarmolovich et al., 2013). The first symptoms of infection in plants appear in early May, when the lower needles of seedlings and saplings become golden brown, and then turn brown and die. The pathogen spreads along the young stem, causing the side shoots of the current year and the apical bud to die. As a result, plant growth is inhibited and the plant eventually dies. Phoma blight of agricultural plants has been known for a long time (causal pathogens are fungi from the genus Phoma Sacc.) (Smith et al., 1992; Fitt et al., 2006), yet studies of the causative agents of Phoma blight of forest trees only initiated in the 1980s.
The fungal species of the genus Phoma are numerous, and are difficult to systematise due to the absence of reproductive organs in most species, and they are characterised by high morphological variability in natural conditions and polyphilia (Boerema et al., 2004; Aveskamp, 2014).

The collection of fungal material by sampling tissues of infected plants was carried out in 36 Belarusian forest nurseries. Morphological identification of isolated pure cultures revealed that members of the Phoma genus were the most common fungi in the affected tissues of coniferous tree species (Pinus sylvestris L. and Picea abies L.). Sequencing of the intergenic transcribed spacer (ITS) region of ribosomal RNA genes using ITS1-F and ITS4-B primers (Gardes and Bruns, 1993) and comparison of the obtained data with NCBI database (www.ncbi.nlm.nih.gov) entries showed that the analysed Phoma isolates were not identical to any other Phoma species regarding the ITS region sequence (Baranov 
et al., 2015). Full genome sequencing of one of the isolates was performed, revealing further genetic differences from other Phoma species (Panteleev et al., 2015). In this context it was concluded that these Phoma isolates represent a new species, which was given the temporary name Phoma sp. 1. $P h$. sp. 1 isolates were compared to each other by use of retrotransposon-based iPBS assays, which revealed the high level of their genetic similarity and differences from isolates of Phoma herbarum Westend and Phoma glomerata (Corda) Wollenw. \& Hochapfel (Škipars et al., 2018), supporting the previous conclusion.

One of the stages of the inclusion of a new fungal species in the taxonomic database and assigning it a name is the description of its vegetative and reproductive structures in vivo and in vitro, as well as description of the conditions of mycelium growth and spore formation (Seifert and Rossman, 2010). A number of in vitro characteristics, like growth rate, optimal temperature, chlamydospore formation, colony appearance, optimal $\mathrm{pH}$ and aeration preference were described by Seredich (2016). With this report on the influence of micro- and macro- elements on in vitro growth of this microorganism, we complete the required descriptions of $P h$. sp. 1 concerning its vegetative and reproductive structures in vitro.

\section{MATERIAL AND METHODS}

The object of this study, the pure culture of the fungus $P h$. sp.1, was isolated from an infected individual of $P$. abies L. with typical symptoms of Phoma blight, collected in the permanent forest nursery of the forest enterprise "Ivatsevichy Leskhoz". It was determined that the isolate does not belong to any described species by analysis of the DNA sequences 18S rRNA gene, 5.8S rRNA gene, 26S rRNA gene, intergenic transcribed spacer regions ITS1 and ITS2 of ribosomal RNA genes, conducted at the Forest Institute of the National Academy of Sciences of Belarus (Siaredzich, 2017; Baranov, unpublished). Comparison of the nucleotide sequence of this isolate with data of the NCBI database for the previously mentioned DNA regions showed that the most closely related species was $P h$. glomerata (97\% level of similarity of genetic material) (Siaredzich, 2017; Baranov, unpublished).

Evaluation of the influence of the presence of basic mineral nutrients on the growth rate of mycelium of $P h$. sp.1 was carried out by introducing various macro- and microelements into starvation agar in different concentrations. The microelements tested included copper, zinc, manganese and boron as copper(II) sulfate, zinc sulfate, manganese(II) sulphate and boric acid, respectively. The micro-element concentrations tested were: $10 \mathrm{mg} / \mathrm{l}, 50 \mathrm{mg} / \mathrm{l}$, and $100 \mathrm{mg} / \mathrm{l}$. These are the concentrations that were also used by Zavertkina, 2007. The impact of the macro-elements nitrogen (urea, $\mathrm{N}$ content at least $46.2 \%$ ), phosphorus (tricalcium phosphate, $\mathrm{P}$ content at least $26.2 \%$ ), potassium (potassium chloride, $\mathrm{K}$ content at least $52 \%$ ) and complex fertiliser (N, $\mathrm{P}_{2} \mathrm{O}_{5}$ and $\mathrm{K}_{2} \mathrm{O}$ content not less than $16 \%$ each) were tested at three concentrations: $0.5 \mathrm{~g} / \mathrm{l}, 1 \mathrm{~g} / \mathrm{l}$ and $2 \mathrm{~g} / \mathrm{l}$. These are the concentrations that are recommended for use in Belarusian forest tree nurseries (Jakimov, 2007). In addition, the impact of dolomite $\left(\mathrm{CaMg}\left(\mathrm{CO}_{3}\right)_{2}\right)$ flour with at least $85 \%$ carbonate content on mycelial growth was tested. Dolomite flour is often used to decrease soil acidity to hamper the growth and development of many types of fungi that prefer a weakly acidic or neutral environment. All experiments were performed in 3-5 replicates for each variant of the experiment.

\section{RESULTS}

The greatest influence on the growth of $P h$. sp1 was exerted by urea, which completely suppressed the growth of mycelium in all tested concentrations. Dolomite flour, which is usually applied to the soil to reduce acidity, inhibited the growth of mycelium by $60 \%$ at a concentration of $2 \mathrm{~g} / \mathrm{l}$ in the medium (Table 1). Thus, a sufficiently strong alkalisation of the medium leads to a fungistatic effect in respect to Ph. sp1.

Table 1. Mycelial growth rate of Phoma sp. 1 at various macro-element concentrations in starvation medium

\begin{tabular}{l|c|c|c}
\hline \multirow{2}{*}{ Source of macro-element } & \multicolumn{3}{c}{ Growth rate, $\mathrm{nm}^{2} / 24 \mathrm{~h}$} \\
\cline { 2 - 4 } & $2 \mathrm{~g} / \mathrm{l}$ & $1 \mathrm{~g} / \mathrm{l}$ & $0.5 \mathrm{~g} / \mathrm{l}$ \\
\hline Control (starvation agar) & \multicolumn{3}{c}{$4.0 \pm 0.5$} \\
Urea & - & - & - \\
Tricalcium phosphate & $2.6 \pm 0.7$ & $2.8 \pm 0.6$ & $3.1 \pm 0.8$ \\
Potassium chloride & $2.9 \pm 0.6$ & $3.0 \pm 0.6$ & $3.5 \pm 0.7$ \\
Complex fertiliser (N, P, K) & $2.5 \pm 0.8$ & $2.5 \pm 0.7$ & $2.1 \pm 0.4$ \\
Dolomite flour & $1.5 \pm 0.1$ & $3.4 \pm 0.7$ & $3.5 \pm 0.7$
\end{tabular}

The use of tricalcium phosphate and potassium chloride at concentrations of $1 \mathrm{~g} / \mathrm{l}$ and $2 \mathrm{~g} / \mathrm{l}$ slowed the growth of mycelium by an average of $30 \%$, compared to the control. A significant difference in comparison to the control was also observed in all variants of the experiment with the use of complex nitrogen-phosphorus-potassium fertiliser. When used, the growth rate of mycelium decreased on average by $40 \%$ and the mycelium changed its structure to feathery, became light-coloured and friable in the center of the colony (Fig. 1).

Evaluation of the effect of micro-elements on the growth of $P h$. sp1 mycelium showed a significant difference, compared to the control, for copper sulphate at concentrations of $50 \mathrm{mg} / \mathrm{l}$ and $100 \mathrm{mg} / \mathrm{l}$; and for zinc sulphate at a concentration of $100 \mathrm{mg} / \mathrm{l}$. The growth rate decreased by $50 \%, 63 \%$, and $32 \%$, respectively, in these conditions (Fig. 2, Table 2).

\section{DISCUSSION}

Providing a comprehensive description of the in vitro properties of a new fungal species is essential for the inclusion of this species in the taxonomic database and assigning it a name. The current report on the influence of macro- and 

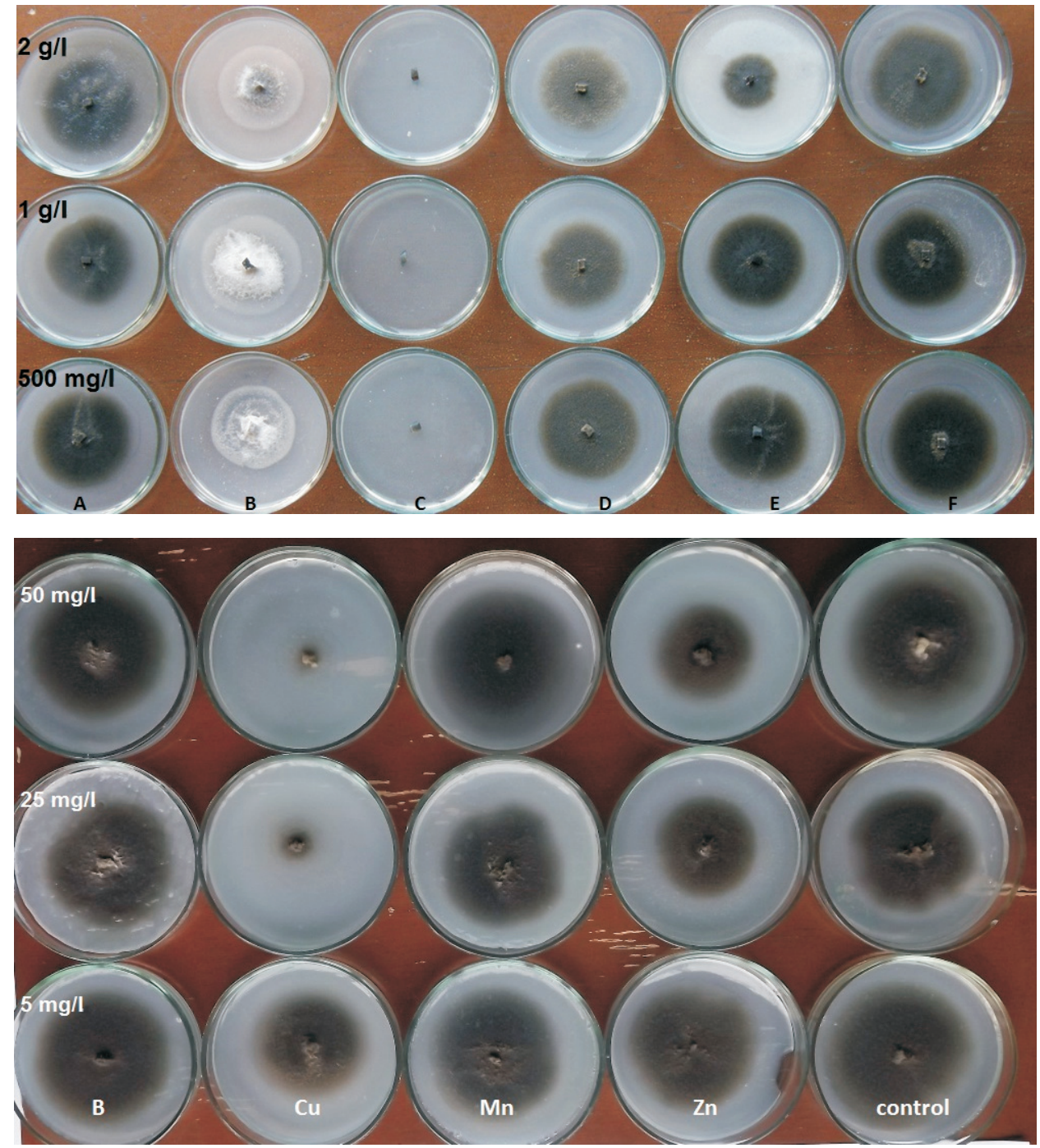

Fig. 1. Effect of macro-elements on mycelial growth of Phoma sp. 1. A, tricalcium phosphate; $\mathrm{B}$, complex fertiliser; C, urea; D, potassium chloride; $\mathrm{E}$, dolomite flour; F, control (starvation agar).
Fig. 2. Effect of micro-elements on growth of Phoma sp. 1 in vitro.
Table 2. The effect of micro-elements on the growth of Phoma sp. 1 in vitro

\begin{tabular}{l|c|c}
\hline $\begin{array}{c}\text { Micro- } \\
\text { element }\end{array}$ & $\begin{array}{c}\text { Concentration } \\
(\mathrm{mg} / \mathrm{l})\end{array}$ & $\begin{array}{c}\text { Colony growth rate, } \\
\mathrm{cm}^{2} / 24 \mathrm{~h}\end{array}$ \\
\hline Copper & 10 & $3.19 \pm 0.51$ \\
& 50 & $2.03 \pm 0.32$ \\
& 100 & $1.51 \pm 0.15$ \\
\hline Zinc & 10 & $4.02 \pm 0.65$ \\
& 50 & $3.49 \pm 0.61$ \\
Manganese & 100 & $2.77 \pm 0.48$ \\
& 10 & $3.83 \pm 0.45$ \\
Boron & 50 & $3.58 \pm 0.58$ \\
& 100 & $3.30 \pm 0.46$ \\
\hline & 10 & $3.90 \pm 0.35$ \\
& 50 & $3.42 \pm 0.49$ \\
& Control & $3.83 \pm 0.46$ \\
\hline
\end{tabular}

micro-elements on mycelial growth and culture morphology complements and refines the description of $P h$. sp. 1 concerning its vegetative and reproductive structures in vitro.

Presence of urea, increased content of nitrogen, copper sulphate and zinc in culture media inhibits $P h$. sp. 1 growth in vitro. The introduction of dolomite flour into the medium also retarded mycelial growth, probably due to the increased sensitivity of the pathogen to alkalisation of the medium. The mentioned effects provide information that is potentially useful for mitigating the economic losses from $\mathrm{Ph}$. sp.1 in tree nurseries.

As this report represents the final step in characterisation of $P h$ sp. 1 in in vitro conditions, we offer a short comparison of some biological features of the growth of the Belarusian isolate Phoma sp. 1 with the morphological description of $P h$. herbarum and Ph. glomerata cited by Boerema et al. (2004) (Table 3).

The main differences of Phoma sp. 1 to these genetically close species are the formation of different types of chlamydospores (or presumed absence of their formation), as well as the morphology of the fungus on oatmeal agar. However, in terms of growth rate, $P h$. sp. 1 is similar to $P h$. glomerata and Ph. herbarum.

Summarising the conclusions from all studies performed on this proposed new species, the plant pathogenic fungus $P h$. sp. 1 cultures showed pronounced polymorphism in various growth and developmental conditions. Phoma sp. 1 does not require special selective media with complex composition 
Table 3. Comparison of in vitro growth characteristics of Ph. sp.1 to Ph. herbarum and Ph. glomerata as described in the Phoma Identification Manual (Boerema et al., 2004) (citing the exact text referring to the subject)

\begin{tabular}{|c|c|c|c|}
\hline $\begin{array}{c}\text { Parameter of } \\
\text { comparison }\end{array}$ & Phoma sp. 1 & Ph. herbarum & Ph. glomerata \\
\hline $\begin{array}{l}\text { Type of } \\
\text { chlamydospores }\end{array}$ & $\begin{array}{l}\text { Chain of } \\
\text { unicellular } \\
\text { chlamydospores }\end{array}$ & $\begin{array}{l}\text { No information about observations of } P h \text {. herbarum } \\
\text { producing chlamydospores is mentioned in the } \\
\text { Phoma Identification Manual nor in any other source } \\
\text { of information to our knowledge }\end{array}$ & $\begin{array}{l}\text { "Chlamydospores highly variable in shape and di- } \\
\text { mensions, generally multicellular-dictyosporous, oc- } \\
\text { casionally solitary-terminal, but usually in branched } \\
\text { or unbranched chains of } 2-20 \text { or more elements, } \\
\text { alternarioid, smooth at first, later roughened, dark } \\
\text { brown to black" }\end{array}$ \\
\hline $\begin{array}{l}\text { Growth rate on } \\
\text { oatmeal agar }\end{array}$ & $4-6.65 \mathrm{~cm}$ & $4-5 \mathrm{~cm}$ & $3.5-7 \mathrm{~cm}$ \\
\hline $\begin{array}{l}\text { The morphology of } \\
\text { fungal colonies on } \\
\text { oatmeal agar }\end{array}$ & $\begin{array}{l}\text { Light grey to } \\
\text { dark grey }\end{array}$ & $\begin{array}{l}\text { "... regular, mostly without any aerial mycelium and } \\
\text { flesh coloured with greenish tinge by the conidial } \\
\text { masses on abundant pycnidia; reverse greenish } \\
\text { olivaceous to olivaceous; mycelial strains or sectors } \\
\text { usually producing a yellowish brown to red diffusible } \\
\text { pigment" }\end{array}$ & $\begin{array}{l}\text { "Most variable in appearance, strains (sectors) with } \\
\text { rather sparse aerial mycelium and abundant aerial } \\
\text { mycelium, dense and woolly in places, olivaceous, } \\
\text { greenish olivaceous, olivaceous buff or dull green; re- } \\
\text { verse dark olivaceous to blackish beneath sectors with } \\
\text { dense mycelium, paler elsewhere" }\end{array}$ \\
\hline
\end{tabular}

for growth and development. The optimal nutrient medium for the cultivation of the fungus is a standard wort agar medium. Colonies of differing colour, texture and density form on various agarised media types. For rapid induction of vegetative spore (chlamydospore) formation, we recommend to grow the $P h$. sp. 1 culture on starvation agar at a temperature of approximately $+4{ }^{\circ} \mathrm{C}$. For the formation and maturation of asexual spores (pycnidia with conidia), specific cultivation conditions are required, which still have to be clarified. Phoma sp. 1 prefers weakly acidic media $(\mathrm{pH}$ 4.3-4.9) for its development, yet it can remain active in acidic and strongly alkaline media. Mycelium of $P h$. sp.1 can be stored for a long time (a year or more) on the same medium without loss of viability.

\section{ACKNOWLEDGEMENTS}

We would like to thank O. Yu. Baranov and S. V. Panteleev from the Forest Institute of the National Academy of Sciences of Belarus for their contribution in sequencing of the DNA of Phoma sp. 1.

\section{REFERENCES}

Aveskamp, M. (2014). Phylogeny and DNA-based identification in Phoma and related genera. PhD Thesis. Wageningen University, Wageningen, Netherlands.

Baranov, O. Yu., Panteleev, S. V., Rubel, I. E., Yarmolovich, V. A., Seredich, M. O. (2015). Identification and annotation of repeating sequences in the genome of Phoma sp. 1. In: Collection of Scientific Papers "Problems of Forestry and Forest Management", Vol. 75. Forest Institute of the National Aademy of Sciences of Belarus, Gomel [Баранов, О. Ю., Пантелеев, С. В., Рубль, И. Е., Ярмолович, В. А., Середич, М. О. Идентификация и аннотация повторяющихся последовательностей в геноме Phoma sp. 1. В кн.: Сборник научных трудов "Проблемы лесоведения и лесоводства”, вып. 75. Институт леса Национальной академии наук Беларуси. Гомель], pp. 183-195 (in Russian).

Baranov, O. Yu., Yarmolovich, V. A., Panteleev, S. V., Kupreenko, D. G. (2012). Molecular-genetic diagnostics of fungal diseases in forest nurseries. Lesnoe i Ohotnich'e Hozjajstvo [Баранов, О. Ю., Ярмолович, В. А., Пантелеев, С. В., Купреенко, Д. Г. Молекулярно-генетическая диагностика грибных болезней в лесных питомниках. Лесное $и$ охотничье хозяйство], 6, 21-29 (in Russian).
Boerema, G. H., de Gruyter, J., Noordeloos, M., Hamers, M. (eds.) (2004). Phoma Identification Manual. CABI Publishing, Cambridge. 470 pp.

Fitt, B. D. L., Brun, H., Barbetti, M. J., Rimmer, S. R. (2006). World-wide importance of phoma stem canker (Leptosphaeria maculans and $L$. biglo-bosa) on oilseed rape (Brassica napus). Eur. J. Plant Pathol., 114 (1), 3-15.

Gardes, M., Bruns, T. D. (1993). ITS primers with enhanced specificity for basidiomycetes - application to the identification of mycorrhizae and rusts. Mol. Ecol., 2 (2), 113-118.

Hansen, E. M., Hamm, P. B. (1988). Canker diseases of Douglas-fir seedlings in Oregon and Washington bareroot nurseries. Can. J. Forest Res., 18 (8), 1053-1058.

Jakimov, N. I., Gvozdev, V. K., Prahodskij, A. N. (2007). Forest Culture and Protective Forestry [Якимов, Н. И., Гвоздев, В. К., Праходский, А. Н. Лесные культуры и защитное лесоразведение]. Belarusian State Technological University, Minsk. 311 pp. (in Russian).

James, R. L. (1986). Mortality of Containerized Western Larch Seedlings at the Champion Timberlands Nursery, Plains, Montana (Report 86-16). United States Forest Service, Montana.

James, R. L. (1998). Phoma branch dieback of 3-0 bare root douglas-fir seedlings USDA forest service nursery, Coeur D'alene, Idaho. Nursery disease notes (No. 136). USDA Forest Service.

Kliejunas, J. T., Allison, J. R., McCain, A. H., Smith, R. S. (1985). Phoma blight of fir and Douglas-fir seedlings in a California Nursery. Plant Dis., 69, 773-775

National Center for Biotechnological Information, NCBI (Electronic resource). http://www.ncbi.nlm.nih.gov (accessed 14 July 2019).

Panteleev, S. V., Baranov, O. Yu., Yarmolovich, V. A., Seredich, M. O., Rubel, I. E. (2015). The analysis of microsatellite loci of the Phoma genome on the basis of full-genomic sequencing. In: Collection of Scientific Papers "Problems of Forestry and Forest Management", Vol. 75. Forest Institute of the National Academy of Sciences of Belarus, Gomel [Пантелеев, С. В., Баранов, О. Ю., Ярмолович, В. А, Середич, М. О., Рубль, И. Е. Анализ микросателлитных локусов генома Рhота на основании полногеномного секвенирования. В кн.: Сборник научных трудов “Проблемы лесоведения и лесоводства”, Вып. 75. Институт леса Национальной академии наук Беларуси. Гомель], pp. 259-263 (in Russian).

Seifert, K. A., Rossman, A. Y. (2010). How to describe a new fungal species. IMA Fungus, 1 (2), 109-116.

Seredich, M.* (2016). Cultural and morphological characteristics of fungus Phoma sp. 1 - Phoma blight causing agents in coniferous tree seedlings. Proceedings of Belarusian State Technological University, 1, 98-101. 
Siaredzich, M. * (2017). Justification of actions for protection of planting material of Scots pine and Norway spruce against Phoma blight in forest nurseries in Belarus [Середич, М. О. Обоснование мероприятий по защите посадочного материала сосны обыкновенной и ели европейской от фомоза в лесных питомниках Беларуси]. Doctoral dissertation, Belarusian State Technological University, Minsk, Belarus. (in Russian).

Škipars, V., Siaredzich, M., Belevich, V., Bruṇeviča, N., Brūna, L., Ruṇǵis, D. E. (2018). Genetic differentiation of Phoma sp. isolates using retrotransposon-based iPBS assays. Environ. Exp. Biol., 16, 307-314.

Smith, I. M., McNamara, D. G., Scott, P. R., Harris, K. M. (eds.) (1992). Quarantine Pests for Europe. Data Sheets on Quarantine Pests for the European Communities and for the European and Mediterranean Plant Protection Organization. CAB International, Wallingford. 1032 pp.

* Ramanenka, M., Seredich, M., and Romanenko M. is the same person.
Srago, M. D., James, R. L., Kliejunas, J. T. (1989). Phoma blight. In: Cordell, C. E., Anderson, R. L., Hoffard, W. H., Landis, T. D., Smith Jr., R. S., Toko, H. V. (eds.). Forest Nursery Pests. Agriculture Handbook No. 680. U.S. Department of Agriculture, Forest Service, pp. 54-55.

Yarmolovich, V., Baranov, O., Dishuk, N., Romanenko, M. * (2013). Phoma blight of planting material in forest nurseries. Lesnoe $i$ Ohotnich'e Hozjajstvo [Ярмолович, В., Баранов, О., Дишук, Н., Романенко, М. Фомоз посадочного материала в лесных питомниках. Лесное $u$ охотничье хозяйство], 3, 18-24 (in Russian).

Zavertkina, I. V. (2007). Biological features of the Siberian population of Phoma exiqua var. foveata and improvement of potato protection system from phoma blight [Заверткина, И. В. Биологические особенности сибирской популяции Phoma exiqua var. foveata и совершенствование системы защиты картофеля от фомоза]. Doctoral dissertation. Novosibirsk State Agricultural University, Kinel, Russian Federation (in Russian).

Received 8 November 2019

Accepted in the final form 8 December 2020

\section{FOMOZI IZRAISOŠĀS SĒNES PHOMA SP.1 KULTŪRAS UN MORFOLOĢISKAIS RAKSTUROJUMS}

Skujkoku stādu fomoze ir maz pētīta. Baltkrievijā galvenā šīs slimības izraisītāja DNS sekvence atškiras no citām aprakstītajām Phoma sugām, un tas vēl nav pilnībā taksonomiski aprakstīts, tāpēc pagaidu nosaukums ir Phoma sp. 1. Šeit aprakstītas galvenās Phoma sp. 1 morfoloğiskās un augšanas kultūras īpašỉbas. Phoma sp. 1 ir mezofils acidofīls, kas spēj veidot hlamidosporas kultūrā. Hlamidosporu veidošanās sākas ar protoplazmas fragmentu atdalīšanos, tad micēlijs sadalās ar starpsienu palīdzību un pārklājas ar biezu apvalku. Hlamidosporu veidošanās visātrāk -7 dienu laikā, norisinājās $+4{ }^{\circ} \mathrm{C}$ temperatūrā. Piknīdijas attīstījās dziḷi barotnē tikai pēc ilgstošas uzglabāšanas zemā temperatūrā, tomēr sporas nenobrieda. Maksimālā biomasas produkcijas intensitāte novērojama pH diapazonā 4,3-4,9, bet sēnes augšana notiek pH diapazonā no 2,5 līdz 8,5, atkarībā no barotnes. Augot suboptimālas pH apstākḷ,os, sēne izmaina barotnes pH, tuvinot to optimumam. Barotnes pH iespaido Phoma sp.1. šūnu un kolonijas morfoloǵiju. Konstanta barotnes aerācija veicina tipiska micēlija veidošanos, proporcionālu augšanu un stabilu biomasas akumulāciju. 